\title{
PENGARUH LAMA PENGERINGAN TERHADAP KARAKTERISTIK FISIKOKIMIA PISANG SALE
}

\author{
The Effect of Drying Time on Physicochemical Characteristics of Banana Sale
}

\author{
Muh Arsyad $^{1 *}$ dan Rum Supu ${ }^{2}$ \\ ${ }^{1,2)}$ Program Studi Agroteknologi, Fakultas Pertanian dan Ilmu Perikanan, Universitas Pohuwato \\ ${ }^{1 *}$ arsyadmaner@gmail.com
}

\begin{abstract}
ABSTRAK
Penelitian ini bertujuan untuk mengetahui pengaruh lama pengeringan terhadap karakteristik fisikokimia dan tingkat penerimaan panelis terhadap pisang sale yang dihasilkan. Penelitian ini dilakukan dengan menggunakan 4 perlakuan dan 3 kali ulangan. Perlakuan yang dimaksud adalah pengeringan 28 jam, pengeringan 35 jam, pengeringan 42 jam, pengeringan 49 jam. Parameter yang diamati meliputi kadar air, gula total, kadar abu dan uji organoleptik terhadap warna, rasa, aroma, dan tekstur pada pisang sale. Penelitian ini menggunakan Rancangan Acak Lengkap (RAL), apabila ada beda nyata dipakai uji lanjut BNJ pada tarif $1 \%$. Hasil penelitian ini menunjukan bahwa lama pengeringan berpengaruh sangat nyata terhadap kadar air, kadar abu dan gula total. Uji tingkat kesukaan terhadap warna, aroma, rasa dan tekstur yang paling disukai oleh panelis adalah perlakuan A1 pengeringan $28 \mathrm{jam}$.
\end{abstract}

\section{Kata kunci: kadar air, pengeringan, pisang sale}

\begin{abstract}
This study aims to determine the effect of drying time on the physicochemical characteristics and the level of panelists' acceptance of the banana sale produced. This research was conducted using 4 treatments and 3 replications. The treatments in question are drying 28 hours, drying 35 hours, drying 42 hours, drying 49 hours. Parameters observed included water content, total sugar, ash content and organoleptic tests on color, taste, aroma, and texture on sale bananas. This study used a completely randomized design (CRD), if there was a significant difference, the BNJ further test was used at a rate of $1 \%$. The results of this study indicate that drying time has a very significant effect on water content, ash content and total sugar. The test of the level of preference for color, aroma, taste and texture that was most favored by the panelists was the Al treatment of 28 hours drying.
\end{abstract}

Keywords: moisture content, drying, banana sale

\section{PENDAHULUAN}

Pisang merupakan salah satu produk pertanian yang melimpah karena dapat tumbuh hampir di seluruh daerah yang ada di Indonesia. Produksi pisang di Indonesia tersebar seluruh daerah Provinsi Gorontalo, salah satu di antaranya Kabupaten Pohuwato. Berdasarkan data yang di peroleh dari Badan Pusat Statistik (BPS, 2020) bahwa produksi pisang lima tahun terakhir mengalami naik turun yaitu pada tahun 2016 dan 2017 produktivitas pisang mencapai 4249 sampai 4951 ton, kemudian pada tahun 2018 produktivitas pisang naik hingga mencapai 5509 ton dan pada tahun 2019 produksi pisang menurun sampai 5111 ton. Meskipun demikian produksi pisang di Kabupaten Pohuwato tetap tinggi. 
Perbal: Jurnal Pertanian Berkelanjutan

Fakultas Pertanian Universitas Cokroaminoto Palopo

Buah pisang dapat di konsumsi dengan berbagai cara, dapat dimakan secara langsung hingga dapat diolah menjadi berbagai macam produk olahan makanan, salah satunya adalah pisang sale atau pisang dampo. Pisang sale merupakan salah satu produk olahan yang sangat digemari oleh masyarakat mulai dari anak-anak sampai dewasa karena rasanya yang manis dan gurih, sangat enak dinikmati dalam keadaan bersantai dirumah. Disamping itu, pisang merupakan makanan yang sehat karena memiliki kandungan gizi nutrisi yang cukup tinggi.

Pengolahan pisang raja menjadi pisang sale dapat meningkatkan keuntungan para petani karena dapat menghemat ongkos produksi dan transportasi serta mempermudah proses pemasaran. Buah pisang yang sudah masak tidak bertahan lama untuk disimpan, dengan adanya pengolahan pisang sale maka akan bertahan lama untuk disimpan. Pisang sale merupakan hasil olahan dari buah pisang masak yang di iris tipis kemudian di awetkan dengan cara pengeringan hingga kadar air pada pisang menurun. Pisang sale merupakan makanan semi basah yang di buat dari pisang masak dengan cara pengeringan tanpa penambahan pengawet. Pengeringan pisang berfungsi untuk mengurangi kadar air pada buah pisang sehingga pisang sale dapat di simpan dan tahan lama sehingga mampu meningkatkan nilai ekonomi pisang (Rahman dkk., 2018).

Mutu pisang sale sangat di pengaruhi oleh cara pengolahan, penyimpanan produk serta jenis pisang yang di gunakan. Pada dasarnya, semua jenis pisang dapat diolah menjadi pisang sale namun tidak semua jenis pisang menghasilkan pisang sale dengan cita rasa yang enak dan memiliki mutu yang baik. Buah pisang yang mengalami kerusakan fisik dan tingkat kematangan kurang optimal akan menghasilkan pisang sale dengan kualitas rendah ditandai dengan warna yang putih kekuningan. Hal ini disebabkan karena kandungan karbohidrat cukup tinggi dan kadar gulanya masih rendah (Prabawati dkk., 2008).

Pengeringan adalah suatu cara untuk mengeluarkan atau menghilangkan sebagian kadar air (water activity) atau Aw dari suatu bahan dengan menggunakan energi panas. Keuntungan pengeringan adalah bahan menjadi lebih tahan lama di simpan dan volume bahan menjadi lebih kecil sehingga mempermudah dan menghemat ruang pengangkutan dan pengepakan. Disisi lain, pengeringan menyebabkan sifat asli bahan mengalami perubahan, penurunan mutu dan memerlukan penanganan tambahan yaitu rehidrasi (Muchtadi, 2009). Pengeringan pisang sale menjadi salah satu faktor utama dalam menentukan kualitas dari pasang sale 
yang dihasilkan. Pisang yang terlalu kering akan menyebabkan permukaan dan kenampakan menjadi keriput dan kehilangan berat yang berlebih, akan tetapi jika pisang sale yang dikeringkan kurang optimal maka akan menghasilkan pisang sale yang memiliki kadar air yang tinggi dan mudah terserang jamur sehingga mempengaruhi mutu dari pisang sale. Berdasarkan hal tersebut, maka perlu dilakukan penelitian tentang "Pengaruh Lama Pengeringan terhadap Karakteristik Fisikokimia Pisang Sale", sehingga pengeringan dilakukan secara optimal untuk menghasilkan kualitas pisang sale yang baik.

\section{METODOLOGI PENELITIAN}

\section{Tempat Penelitian}

Penelitian ini merupakan penelitian laboratorium dan dilaksanakan dari bulan Oktober sampai Desember 2021. Penelitian ini dilaksanakan di laboratorium Pertanian, Universitas Pohuwato. Uji organoleptik dan uji proksimat di Balai Besar Industri Hasil Perkebunan Makassar.

\section{Alat dan Bahan}

Alat yang di gunakan dalam penelitian ini yaitu baskom, wajan, timbangan, wadah penjemur, kompor gas, spatula, sendok, pisau, wadah pengumpul, kemasan, oven, cawan, desikator, tanur dan refraktometer. BahanBahan yang di gunakan dalam penelitian ini adalah buah pisang raja, kertas label, minyak goreng, aquadest, $\mathrm{H}_{2} \mathrm{SO}_{4} 0,02 \mathrm{~N}$, dan $\mathrm{HBO}_{3}$.

\section{Prosedur Penelitian}

Prosedur yang dilakukan pada penelitian yaitu disiapkan pisang raja yang sudah masak ditandai dengan semua warna kulit yang sudah menguning sebanyak $4 \mathrm{~kg}$. Pisang raja yang sudah disiapkan kemudian dibelah menjadi dua bagian menggunakan pisau. Pisang dipisahkan berdasarkan perlakuan masing-masing $1 \mathrm{~kg}$, kemudian dilakukan penjemuran dengan menggunakan sinar matahari. Pisang yang sudah dijemur pada hari kedua setelah pengeringan di kupas kulit yang masih menempel. Setiap sore pisang yang sudah dikeringkan dikumpulkan didalam wadah dan ditutup rapat untuk meningkatkan kemanisan pada pisang sale. Pada pagi hari pisang sale kemudian disebar kembali pada wadah penjemuran, dan dilakukan sesuai perlakuan yaitu 28 jam, 35 jam, 42 jam, dan 49 jam pengeringan. Pisang sale yang sudah dijemur kemudian dilakukan penimbangan untuk mengetahui rendemen, dan dikemas untuk dilakukan uji proksimat dan uji organoleptik. Untuk uji organoleptik terhadap rasa, terlebih dahulu pisang sale digoreng sebelum di uji.

Perlakuan Penelitan

Perlakuan yang digunakan dalam penelitian ini adalah sebagai berikut : 
Perbal: Jurnal Pertanian Berkelanjutan

Fakultas Pertanian Universitas Cokroaminoto Palopo

A1: Lama penjemuran sinar matahari 28 jam

A2: Lama penjemuran sinar matahari 35 jam

A3: Lama penjemuran sinar matahari 42 jam

A4: Lama penjemuran sinar matahari 49 jam

\section{Parameter Pengamatan}

\section{Penentuan Kadar Air (SNI 012891 1992)}

Kadar air di tentukan dengan cara pengeringan di dalam oven. Bahan di timbang sebanyak \pm 3 g. Dimasukkan dalam cawan yang telah diketahui beratnya, kemudian masukkan ke dalam oven yang bersuhu $105^{\circ} \mathrm{C}$ selama 4 jam. Kemudian sampel didinginkan dalam desikator selama 10 menit dan ditimbang. Panaskan lagi dalam oven selama 1 jam, dinginkan dalam desikator selama 10 menit dan ditimbang. Perlakuan ini di ulangi sampai tercapai berat yang konstan (selisih penimbangan berturut-turut tidak lebih dari $0,02 \mathrm{~g})$.

$\%$ Kadar air $=\frac{\text { Berat awal-berat akhir }}{\text { berat awal }} \times 100 \%$

\section{Penentuan Kadar Gula Total (SNI 012892} 1992)

Analisa total gula dilakukan dengan menggunakan refraktometer. Prinsip kerja refraktometer adalah menyerap cahaya yang terdapat pada sampel. Prosedur kerja: sampel dihaluskan, kemudian diteteskan pada prisma. Refraktometer menghasilkan data total gula dalam satuan brix.

\section{Penentuan Kadar Abu (SNI 012891 1992)}

Kadar abu ditentukan dengan analisis pada bahan pangan diawali dengan menyiapkan kurs porselin. Prosedur kerja sebagai berikut: timbang 2 gr -3 gr sampel pisang sale dalam sebuah cawan porselen (atau platina) yang telah diketahui bobotnya, dengan cara arangkan diatas nyala pembakaran lalu abukan dalam tanur listrik pada suhu maksimum $550^{\circ} \mathrm{C}$ sampai pengabuan sempurna (sekali-kali pintu tanur dibuka sedikit, agar oksigen bisa masuk). Dengan cara didinginkan dalam eksikator, lalu timbang sampai bobot tetap. Peralatan labu didih $500 \mathrm{ml}$ beserta batu didih.

Perhitungan:

$$
\% \text { Kadar } a b u=\frac{(\mathrm{WI}-\mathrm{W} 2)}{W} \times 100 \%
$$

Dimana:

W adalah bobot sebelum diabukan, dalam gr. WI adalah bobot contoh + cawan sesudah diabukan dalam gr.

\section{Analisis Organoleptik}

Panelis yang akan menguji berjumlah 25 orang. Uji organoleptik yang dilakukan meliputi tekstur, aroma, warna, dan rasa dari pisang sale yang disajikan. Kemudian panelis diminta untuk memberikan nilai menurut tingkat kesukaan. Jumlah hedonik yang digunakan yaitu ( 1 ) = Sangat tidak suka; ( 2 ) = Tidak Suka ; $(3$ ) = Agak Suka; $(4)=$ Suka; $(5)=$ Sangat Suka. 


\section{Pengolahan Data}

Rancangan percobaan yang di gunakan adalah rancangan acak lengkap (RAL) dan sebagai perlakuan yaitu lama pengeringan 28 jam, 35 jam, 42 jam dan 49 jam. Parameter yang di amati yaitu: kadar air, kadar abu dan kadar gula. Rumus perhitungan yaitu sebagai berikut:

$$
Y i j=\mu+\alpha i+\sum i j
$$

Dimana:

Yij = Pengamatan pada perlakuan lama pengeringan ke-i dan ulangan ke-j

$\mu=$ Nilai rataan umum pengamatan

$\alpha \mathrm{i}=$ Pengaruh faktor lama pengeringan ke-i

$\mathrm{i}=1,2, \ldots \ldots . \mathrm{t}$

$\mathrm{j} \quad=1,2, \ldots, \mathrm{r}$

$\sum_{\mathrm{ij}}=$ Pengaruh galat perlakuan lama pengeringan ke-i, dan ulangan ke-j

\section{HASIL DAN PEMBAHASAN}

\section{Kadar Air}

Kadar air merupakan persentase jumlah air yang terdapat pada bahan pangan. Persentase kadar air sangat menentukan mutu dari suatu bahan pangan. Kadar air yang tinggi akan menyebabkan bahan pangan akan cepat mengalami kerusakan dan tumbuhnya jamur serta bakteri yang tidak diinginkan Akan tetapi, jika kadar air terlalu rendah akan menyebabkan mutu organoleptik akan menurun sehingga kurang disukai oleh konsumen sehingga air pada bahan pangan memiliki peranan penting dalam penentuan kesegaran, flavor, dan mutu dari bahan pangan. Berdasarkan hasil penelitian pada pengeringan pisang sale dapat dilihat pada gambar 1 sebagai berikut :

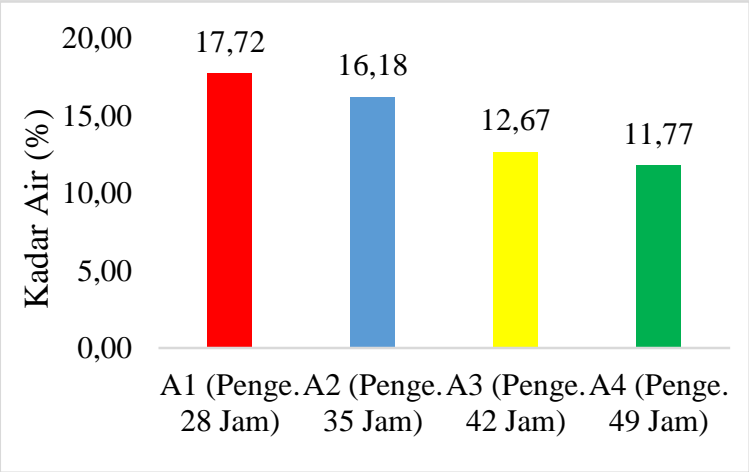

Gambar 1. Kadar air pisang sale

Berdasarkan hasil penelitian dapat dilihat pada Gambar 1 yaitu terjadi penurunan kadar air pada pisang sale selama dikeringkan. Pada perlakuan A1 dengan pengeringan 28 jam memiliki kadar air 17,72\%, untuk perlakuan A2 dengan pengeringan 35 jam memiliki kadar air 16,18\%, perlakuan A3 dengan pengeringan 42 jam memiliki kadar air $12,67 \%$ dan perlakuan A4 dengan pengeringan 49 jam memiliki kadar air 11,77\%. Berdasarkan data tersebut maka dapat diketahui bahwa terjadi penurunan kadar air selama masa pengeringan pada pisang sale. Semakin lama dikeringkan makan kadar air pada pisang sale semakin menurun. Penurunan kadar air pada pisang sale disebabkan oleh suhu pengeringan, sehingga tekanan uap air yang terdapat pada pisang meningkat menyebabkan terjadi perpindahan air dari pisang sale menuju lingkungan. Kondisi ini akan menyebabkan terjadi penurunan kadar air 
Perbal: Jurnal Pertanian Berkelanjutan

Fakultas Pertanian Universitas Cokroaminoto Palopo

pada pisang sale. Hal ini sesuai dengan pendapat Sinurat (2014), bahwa terjadi penurunan kadar air pada bahan akibat adanya ketidakseimbangan pada bahan sehingga terjadi perpindahan air dari bahan menuju lingkungan. Hal ini diperkuat oleh Arsyad (2018), bahwa suatu bahan dalam keadaan seimbang apabila laju kehilangan air dari bahan ke udara sekelilingnya sama dengan laju penambahan air ke bahan dari udara disekelilingnya Penurunan kadar air pada bahan juga dipengaruhi oleh pengeringan yang dilakukan pada pisang sale untuk perlakuan yang lain yang lebih lama yaitu 35 jam, 42 jam dan 49 jam, sehingga semakin lama pengeringan kadar air semakin menurun. Hal ini dikemukakan oleh Taufiq (2004), bahwa terjadi penurunan kadar air sejalan dengan kenaikan suhu dan lama waktu pengeringan pada bahan pangan.

Lama pengeringan akan memberikan pengaruh sangat nyata terhadap kadar air, hal ini disebabkan oleh kandungan air yang terdapat pada bahan pangan yang mudah diuapkan pada permukaan bahan dan berkurang seiring dengan lama pengeringan yang dilakukan. Selama proses pengeringan, air yang terikat bebas akan dengan mudah dikeluarkan pada pisang sale. Hal ini sesuai dengan pendapat Darun (2012), yang menjelaskan dalam bahan pangan, air terikat secara bebas, fisik dan kimia. Pengeringan pada bahan pangan akan menyebabkan air yang terikat secara bebas mudah diuapkan, akan tetapi air yang terikat secara fisik dan kimia memerlukan perlakuan khusus pada saat proses pengeringan. Kadar air yang dihasilkan pada pisang sale memenuhi standar SNI syarat mutu pisang sale, dimana kadar air pisang sale maksimal 40\%, sedangkan kadar air yang dihasilkan pada penelitian ini hanya berkisar $11,77 \%$ sampai $17,72 \%$, sehingga kadar air ini sangat memenuhi syarat mutu pisang sale.

\section{Kadar Gula Total}

Gula merupakan bagian dari karbohidrat yang lebih sederhana yang banyak digunakan dalam kehidupan sehari hari. Kadar gula merupakan persentase kandungan gula yang terdapat pada bahan pangan. Gula merupakan sumber energi sehingga menjadi bahan pokok yang diperlukan oleh masyarakat. Gula sebagai sukrosa diperoleh dari nira tebu, bit gula, atau aren. Kadar gula dalam bahan pangan seringkali berbeda-beda tergantung dari perlakuan dan cara pengolahan bahan pangan. Salah satu yang mempengaruhi kadar gula dalam bahan pangan adalah pengolahan, pemanasan atau pengeringan. Hasil penelitian pengeringan pisang sale mempengaruhi kadar gula pada pisang. Hasil dapat dilihat pada gambar 2 sebagai berikut: 


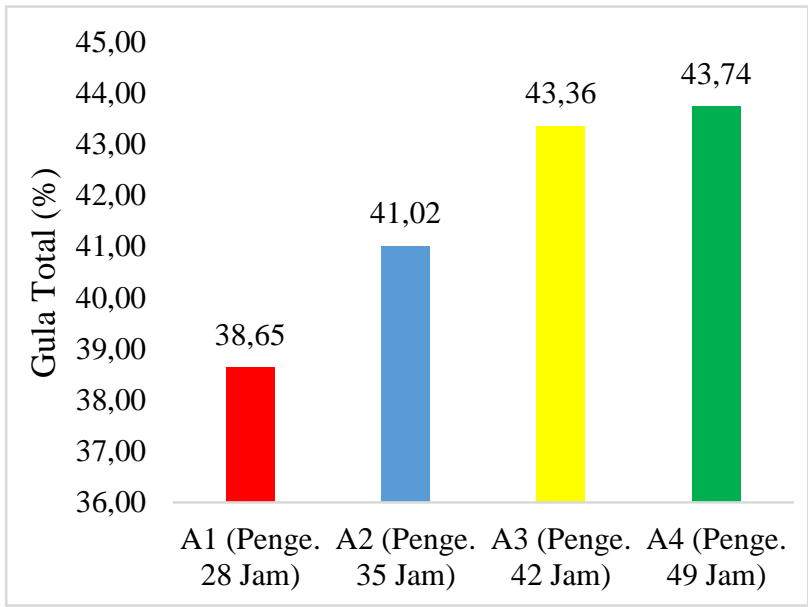

Gambar 2. Kadar gula total pisang sale

Berdasarkan hasil penelitian tentang gula total dapat dilihat pada Gambar 2, bahwa pada perlakuan A1 dengan pengeringan 28 jam memiliki gula total $38,65 \%$, pada perlakuan A2 dengan pengeringan 35 jam memiliki gula total $41,02 \%$, perlakuan A3 dengan pengeringan 42 jam memiliki gula total $43,36 \%$ dan perlakuan A4 dengan pengeringan 49 jam memiliki gula total $43,74 \%$. Selama pengeringan 28 jam sampai pada pengeringan 49 jam pada pisang sale terjadi peningkatan kadar gula total mulai dari $38,65 \%$ sampai $43,74 \%$.

Peningkatan kadar gula tertinggi pada pisang sale terjadi pada perlakuan pengeringan A4 dengan kadar gula total 43,74\% dengan waktu pengeringan 49 jam atau pengeringan matahari selama 7 hari (pengeringan dilakukan dalam 1 hari sekitar 7 jam), sedangkan kadar gula terendah pada perlakuan A1 dengan waktu pengeringan 28 jam atau pengeringan matahari selama 4 hari (pengeringan dilakukan dalam 1 hari sekitar 7 jam). Peningkatan kadar gula total pada pisang sale akibat dari penurunan kadar air pada pisang sale sehingga kadar kemanisannya meningkat. Akan tetapi, jika kadar airnya tinggi maka kadar gula akan menurun, begitu juga dengan tingkat kemanisan pada pisang sale. Hal ini sesuai dengan pendapat Rahman dkk. (2018), bahwa penurunan gula reduksi sale pisang berhubungan dengan adanya peningkatan kadar air pada sale pisang selama penyimpanan. Hal ini juga didukung oleh pernyataan Indradewi (2016), bahwa pengolahan pisang sale secara tradisional hanya membutuhkan waktu pengeringan 4 sampai 6 hari dengan mutu dan tingkat kemanisan yang baik. Berdasarkan standar SNI menunjukkan bahwa semua perlakuan pada pisang sale memenuhi standar. Batas minimum kadar gula pada syarat mutu pisang sale yaitu minimum $35 \%$, sedangkan pisang sale yang dihasilkan memiliki kadar gula total berkisar $38,65 \%$ sampai $43,74 \%$.

\section{Kadar Abu}

Kandungan mineral pada bahan pangan juga dikenal dengan nama kandungan kadar abu. Kadar abu merupakan suatu zat anorganik yang terdapat pada bahan pangan yang didapat melalui pembakaran suatu bahan organik. Kadar abu yang terkandung dalam bahan pangan tergantung dari macam bahan yang 
dugunakan. Berdasarkan hasil penelitian, maka kadar abu pada pisang sale dapat dilihat pada gambar 3 sebagai berikut:

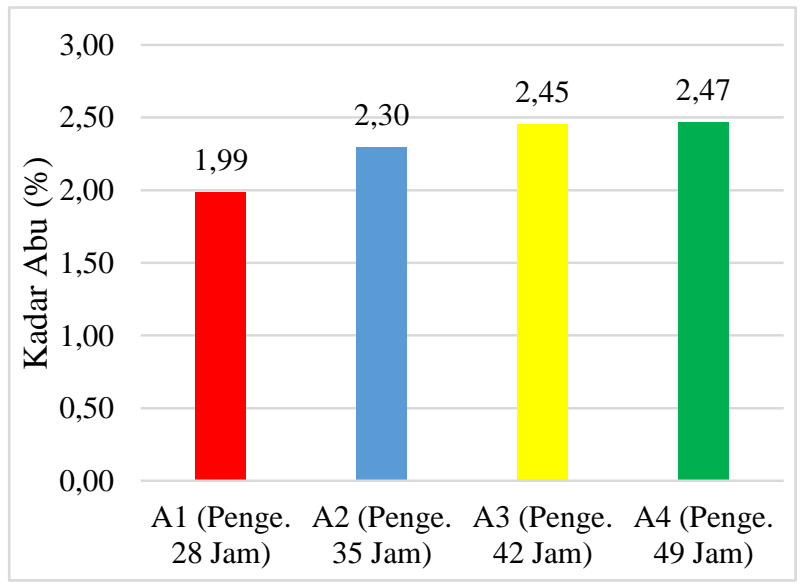

Gambar 3. Kadar abu pisang sale

Berdasarkan gambar 3 menunjukkan bahwa terjadi peningkatan kadar abu pada pisang sale selama proses pengeringan. Pada perlakuan A1 lama pengeringan 28 jam memiliki kadar abu 1,99\%, perlakuan A2 lama pengeringan 35 jam memiliki kadar abu 2,30\%, perlakuan A3 lama pengeringan 42 jam memiliki kadar abu 2,45\% dan perlakuan A4 lama pengeringan 49 jam memiliki kadar abu $2,47 \%$.

Berdasarkan gambar 3 menunjukkan bahwa terjadi peningkatan pada kandungan kadar abu pada pisang sale. Hal ini berbanding terbalik dengan kadar air pada pisang sale, dimana pengeringan yang lama akan menurungkan kadar air tetapi akan meningkatkan kadar abu pada pisang sale yang digunakan. Kadar abu atau kandungan mineral pada bahan tidak mudah menguap hanya karena pengeringan. Sehingga jika kadar air tinggi akan menurunkan kadar abu, tetapi jika dilakukan pengeringan yang lama maka kadar air menurun dan kadar abu meningkat. Hal ini sesuai dengan pendapat Sudarmadji dkk. (2006), bahwa kadar abu adalah komponen yang berisi unsur mineral yang tertinggal setelah bahan dibakar hingga bebas dari karbon dan air. Komponen ini tidak mudah menguap pada proses pembakaran dan pemijaran senyawa organik. Hal ini juga didukung oleh Erni dkk. (2018), bahwa kadar abu dipengaruhi oleh faktor suhu dan lama pengeringan. Hal ini diduga karena semakin lama dan tinggi suhu pengeringan yang digunakan akan meningkatkan kadar abu, dikarenakan kadar air yang keluar dari dalam bahan semakin besar. Berdasarkan SNI syarat mutu pisang sale dari kadar abu maksimal $2 \%$, perlakuan A1 sudah memenuhi standar yaitu $1,99 \%$, sedangkan perlakuan yang lainnya melebihi $2 \%$ atau tidak sesuai dengan standar SNI.

\section{Analisis Organoleptik}

Hasil uji organoleptik pisang sale didapatkan bahwa lama pengeringan memberikan pengaruh terhadap uji kesukaan panelis. Pengeringan yang dilakukan 28 jam pada perlakuan A1 lebih disukai oleh panelis baik dari segi warna, aroma, rasa dan tekstur. 
Warna yang dihasilkan oleh perlakuan A1 lebih disukai oleh panelis karena memiliki warna yang cerah dibandingkan perlakuan yang lain yang sudah mengalami perubahan warna menjadi coklat. Rasa pisang sale lebih disukai pada perlakuan A1 karena rasa pisang lebih terasa dibandingkan dengan perlakuan yang lain. Pada parameter rasa pisang sale kurang terasa akibat pengeringan yang terlalu lama. Pengeringan juga menurunkan tingkat kesukaan terhadap aroma pisang sale, begitu juga dengan tekstur pisang sale yang sudah kering akibat menurunnya kadar air akibat pengeringan sehingga panelis lebih menyukai perlakuan A1.

\section{KESIMPULAN DAN SARAN}

\section{Kesimpulan}

Lama pengeringan pisang sale memberikan pengaruh yang sangat nyata terhadap kadar air, kadar abu dan kadar gula total. Kandungan kadar air yang tertinggi terdapat pada perlakuan A1 berkisar 17,72\%, terendah terdapat pada perlakuan A4 11,77\%, kandungan kadar abu yang tertinggi terdapat pada perlakuan A4 2,47\% dan terendah terdapat pada perlakuan A1 1,99\%, kandungan kadar gula total tertinggi diperoleh pada perlakuan A4 43,74\% dan yang terendah terdapat pada perlakuan A1 $38,65 \%$. Lama pengeringan pisang sale dari warna, aroma, rasa dan tekstur dari penilaian panelis tertinggi pada perlakuan A1.

\section{Saran}

Saran untuk penelitian selanjutnya sebaiknya dilanjutkan penelitian tentang uji masa simpan terhadap pisang sale.

\section{DAFTAR PUSTAKA}

Arsyad, M. (2018). Pengaruh Pengeringan terhadap Laju Penurunan Kadar Air dan Berat Jagung (Zea mays L.) untuk Varietas Bisi 2 dan NK22. Agropolitan. Vol.5, No.1.

Badan Pusat Statistik [BPS]. (2020). Data Produksi Pisang kabupaten Pohuwato.https://pohuwatokab.bps.go .id/. Diakses pada tanggal 24 Desember 2021.

Darun, S. (2012). Pengaruh Suhu Pengeringan dan Lama Pengeringan terhadap Mutu Jagung Pipilan. Universitas Sumatera Utara. Sumatera Utara.

Erni, N., Kadirman, R. Fadilah. (2018). Pengaruh Suhu dan Lama Pengeringan terhadap Sifat Kimia dan Organoleptik Tepung Umbi Talas (Colocasia esculenta). Jurnal Pendidikan Teknologi Pertanian. Vol. 4: 95-105.

Indradewi, F. (2016). Pengaruh Teknik Pengeringan terhadap Kadar Gizi dan Mutu Organoleptik Sale Pisang (Musa paradisiaca L.). JF FIK UINAM. Vol.4, No.2.

Muchtadi, D. (2009). Pengantar Ilmu Gizi. Alfabeta. Bandung.

Prabawati, S., Suyanti dan D.A. Setyabudi. (2008). Teknologi Pasca Panen dan Teknik Pengolahan Buah Pisang. Balai Besar Penelitian dan Pengembangan 
Perbal: Jurnal Pertanian Berkelanjutan

Fakultas Pertanian Universitas Cokroaminoto Palopo

Pascapanen Pertanian Badan

Penelitian dan Pengembangan

Pertanian (Juknis Pisang).

Rahman, A.N.F., M. Mahendradatta dan J. Effendi. (2018). Pengaruh Kemasan terhadap Mutu Sale Pisang Raja (Musa x paradisiaca $\quad A A B) \quad$ Selama Penyimpanan. Canrea Journal. Vol. 1 , issue 2.

Sinurat, E. dan M. Murniyati. (2014). Pengaruh Waktu dan Suhu Pengeringan terhadap Kualitas Permen Jeli. JPB Perikanan. Vol. 9 No. 2:133-142.
Standar Nasional Indonesia [SNI]. (1996). SNI Syarat Mutu Sale Pisang. SNI 014319-1996. Jakarta.

Sudarmadji, S., B. Haryono \& Suhardi. (2006). Prosedur Analisa untuk Bahan Makanan dan Pertanian. Penerbit Angkasa. Bandung.

Taufiq, M. (2004). Pengaruh Temperatur terhadap Pengeringan Jagung pada Pengeringan Konvensional. Fakultas Teknik-Universitas Sebelas Maret. Surakarta. 